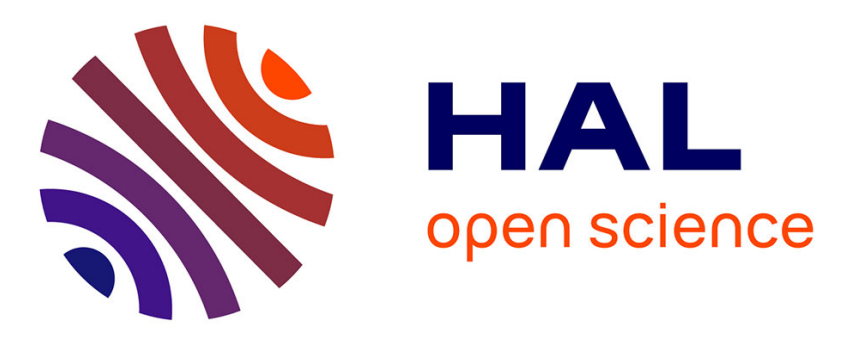

\title{
Mites of the family Phytoseiidae (Acarina, Mesostigmata) as predators of the Japanese bayberry whitefly, Parabemisia myricae Kuwana (Hom., Aleyrodidae) (1) \\ Manes Wysoki, Martine Cohen
}

\section{To cite this version:}

Manes Wysoki, Martine Cohen. Mites of the family Phytoseiidae (Acarina, Mesostigmata) as predators of the Japanese bayberry whitefly, Parabemisia myricae Kuwana (Hom., Aleyrodidae) (1). Agronomie, 1983, 3 (8), pp.823-825. hal-00884576

\section{HAL Id: hal-00884576 https://hal.science/hal-00884576}

Submitted on 1 Jan 1983

HAL is a multi-disciplinary open access archive for the deposit and dissemination of scientific research documents, whether they are published or not. The documents may come from teaching and research institutions in France or abroad, or from public or private research centers.
L'archive ouverte pluridisciplinaire HAL, est destinée au dépôt et à la diffusion de documents scientifiques de niveau recherche, publiés ou non, émanant des établissements d'enseignement et de recherche français ou étrangers, des laboratoires publics ou privés. 


\title{
Mites of the family Phytoseiidae (Acarina, Meso- stigmata) as predators of the Japanese bayberry whitefly, Parabemisia myricae Kuwana (Hom., Aleyrodidae) ${ }^{1}$ )
}

\author{
Manes WYSOKI \& Martine COHEN $(*)$ \\ Division of Entomology, Institute of Plant Protection, Agricultural Research Organization, The Volcani \\ Center, ISR 50250 Bet Dagan \\ (*) Laboratory of experimental Entomology, University of Amsterdam, 10985 M. Amsterdam
}

The Japanese bayberry whitefly, Parabemisia myricae (Kuwana) (Hom., Aleyrodidae), a newly introduced pest of avocado and citrus in Israel, is attacked by two predacious mites, Euseius rubini Swirski \& Amitai, and Amblyseius swirskii Athias-Henriot (Mesostigmata : Phytoseiidae). Adults of E. rubini preyed on all stages of this whitefly ; larvae attained adulthood when fed on eggs and larvae of $P$. myricae, but reached only nymphal stages when fed on 2nd and 3rd instars. The adults of $A$. swirskii fed on eggs and larvae and on 2nd and 3rd instars, and continued to lay eggs. The young stages of $A$. swirskii attained adulthood only when fed on eggs and larvae of $P$. myricae ; when fed on 2 nd and 3 rd instars they died in the nymphal stage. A survey was made of E. rubini in association with $P$. myricae in avocado orchards.

Additional key words : Euseius rubini, Amblyseius swirskii, predation, avocado, citrus.

RÉSUMÉ

Acariens de la famille des Phytoseiidae (Acarina, Mesostigmata), prédateurs de l'aleurode du laurier-cerise, Parabemisia myricae Kuwana (Hom., Aleyrodidae).

L'aleurode du laurier-cerise japonais, Parabemisia myricae (Kuwana) (Hom. Aleyrodidae), ravageur nouvellement introduit en Israël sur avocatiers et citrus, est attaqué par deux acariens prédateurs, Euseius rubini Swirski \& Amitai, et Amblyseius swirskii Athias-Henriot (Mesostigmata, Phytoseidae). Les adultes d'E. rubini se nourrissent aux dépens de tous les stades de l'aleurode; les larves ne parviennent au stade adulte que si elles s'alimentent aux dépens des œufs et des larves mobiles du $1^{\text {er }}$ stade de $P$. myricae; nourries sur les larves des $2^{e}$ et $3^{e}$ stades, elles ne parviennent qu'au stade nymphal. Les adultes $\mathrm{d}^{\prime} A$. swirskii s'alimentent aux dépens des œufs et des larves mobiles puis des larves du $2^{\mathrm{e}}$ et $3^{\mathrm{e}}$ stade et continuent à pondre les œufs. Les jeunes stades d'A. swirskii atteignent l'âge adulte uniquement lorsqu'elles se nourrissent aux dépens des cufs et des larves mobiles de $P$. myricae ; alimentés avec des larves du $2^{\mathrm{e}}$ et $3^{\mathrm{e}}$ stades, ils meurent au stade nymphal. Un examen de l'association E. rubini-P. myricae a été réalisé en vergers d'avocatiers.

Mots clés additionnels : Euseius rubini, Amblyseius swirskii, prédation, avocat, citrus.

\section{INTRODUCTION}

The Japanese bayberry whitefly, Parabemisia myricae (Kuwana), a newly introduced pest in Israel (STERNLICHT, 1979), causes serious damage to citrus and somewhat less damage to avocado plantations (SWIRSKI et al., 1980a; 1980b). The pest occurs also on other plants (SWIRSKI $e t$ al., 1980a). At the same time the pest was reported as new in

(1) Contribution from the Agricultural Research Organization, Bet Dagan, Israel. No. 424-E, 1982 series.
California (Anon., 1978; Rose et al., 1981). In Japan (KUWANA, 1927), its country of origin, the pest is successfully controlled by the parasitic wasp Encarsia (= Prospaltella) bemisiae (Ishii) (Hymenoptera, Aphelinidae) (IsHII, 1938 ; YASUMATSU \& WATANABE, 1965). In Israel some natural enemies imported from other countries were released in the field: e.g. Eretmocerus sp. (Hymenoptera, Aphelinidae) sent by M. ROSE and P. DEBACH from California ; Delphastus pusillus (Leconte) and Nephaspis amnicola Win. (Coleoptera, Coccinellidae) sent by POYUNG LAI from Hawaii ; Cybocephalus binotatus Grouvelle (Coleoptera, Cybocephalidae) from laboratory culture of D. 
BLUMBERG, originally from Pakistan. The establishment of these natural enemies in Israel is not yet known. Several local natural enemies were observed to prey on this pest : coccinellids, chrysopids (Chrysopa carnea Stephens), and a heteropterous predator from the family Anthocoridae (SWIRSKI et al., 1982). Predatory mites from the family Phytoseiidae were found in considerable numbers associated with this pest, particularly Euseius rubini (Swirski \& Amitai) and Amblyseius swirskii Athias.Henriot (SwIRSKI et al., 1982); the former is more abundant in avocado orchards, and the latter in citrus plantations (WYSOKI \& SWIRSKI, 1971). In a Bet Dagan orchard, as many as 50 predatory mites of $E$. rubini were observed on one avocado leaf infested with $P$. myricae.

Laboratory trials were conducted to clarify the predatory habit of these mites on $P$. myricae.

\section{MATERIALS AND METHODS}

The laboratory culture of E. rubini was started from mites collected in avocado orchards at Bet Dagan heavily infested with $P$. myricae. The $A$. swirskii used in those experiments were from a laboratory culture of 9 years on Carpobrotus edulis N. Bal. pollen, so they were well adapted to this food. This strain is even less effective as a predator (RAGUSA \& SWIRSKI, 1977). The mites were bred according to SWIRSKI et al. (1967) and all stages of $P$. myricae collected from the field were supplied as food. The experiments were done on small plates ( $3 \mathrm{~cm}$ diameter), with a base plate on which a sponge and filter paper were placed to ensure moisture for the avocado leaf used as substrate. A plastic cover with a $3 \mathrm{~cm}$ opening was placed on the leaf and fixed in place by 2 metal clips. A barrier consisting of Canada balsam and castor bean oil (1:1) surrounded the plate to prevent the mites from escaping. The experiments were conducted in incubators at a constant temperature of $27 \pm 1{ }^{\circ} \mathrm{C}, 70 \%$ R.H., and $16 \mathrm{~h}$ light $/ 8 \mathrm{~h}$ dark regime.

\section{RESULTS}

\section{A. Field records}

In many avocado orchards of Israel E. rubini was found in association with $P$. myricae, and was observed to prey on the pest. The records are as follows (coll. with E. SwIRSKI and det. with E. SwIRSKI \& S. AMITAI) : Rosh Haniqra 19.XI.81, Matzuba 6.II.79, 20.III.81, 19.XI.81, Eylon 6.II.79, Cabri 6.II.79, 20.III.79 (abundant), Yehiam 5.IX.79, Regba 6.II.79, 19.XI.81 (Western Galilee); Daphna (abundant), Mulata, Sade Eliezer (abundant), Yesod Hamaala, Gadot, Shefer, 24.IX.81, (Upper Galilee and Hula Valley); Arbel 8.XII.81 (Lower Galilee); En HaShofet 8.XII.81 (Mt. Carmel) ; Bet She'arim, Kibbutz Sarid, Megiddo 8.XII.81 (Yizre'el Valley) ; Ramat Yohanan 23.VII.79, 'En Shemer (abundant), 'En HaHoresh, Nahshonim, Ramat HaKovesh 31.VIII.81, Ga'ash 21.IX.79 ; 31.VIII.81 (abundant), Bet Dagan V.81 (abundant) (Coastal Plain); Tequma 25.II.82 (Negev).

\section{B. Laboratory experiments}

The laboratory experiments and field observations show that the adults of $E$. rubini prey on all stages of $P$. myricae, even on newly emerged whiteflies that still do not have extended wings. The mites were observed copulating and laying eggs. Moreover, when the mite populations started from larvae, they attained adulthood and laid eggs when fed on the eggs and larvae of $P$. myricae (table 1 ). The same populations (from larvac of E. rubini) when started on 2nd and 3rd instars, were not successful and the mite reached only nymphal stages. Nymphs of $E$. rubini attacked the eggs and larvae and reach adulthood, but if they preyed on 2 nd and 3rd instars they did not reach adulthood. Laboratory mass rearing of $P$. myricae was successful for 6 generations.

In preliminary experiments with $A$. swirskii, the mites preyed on $P$. myricae. The adults fed on eggs and larvae and continued to lay eggs (average of $0.35 \mathrm{egg} / \mathrm{female} /$ day), as they did when fed on 2nd and 3rd instars $(0.28 \mathrm{egg} / \mathrm{female} /$ day $)$. The young stages of this predator did

\section{TABLE 1}

Effects of Parabemisia myricae (Kuwana) as a prey on the development and fecundity of Euseius rubini (Swirski \& Amitai). Relation entre le stade de la proie consommée (Parabemisia myricae Kuwana), le développement et la fécondité du prédateur (Euseius rubini Swirski \& Amitai).

\begin{tabular}{|c|c|c|c|c|c|c|}
\hline \multirow{3}{*}{$\begin{array}{l}\text { Stages of } \\
P . \text { myricae } \\
\text { as a food }\end{array}$} & \multicolumn{6}{|c|}{ E. rubini } \\
\hline & \multirow{2}{*}{ Active stages } & \multirow{2}{*}{$\begin{array}{c}\text { Initial } \\
\text { population }\end{array}$} & \multicolumn{3}{|c|}{ Attaining adulthood } & \multirow{2}{*}{$\begin{array}{c}\text { 6-day } \\
\text { oviposition } \\
\text { rate } \\
\text { (eggs/female/day }\end{array}$} \\
\hline & & & females & males & $\%$ & \\
\hline \multirow[t]{3}{*}{ Eggs and larvae } & larvae & 20 & 13 & 7 & 100 & 1.01 \\
\hline & nymphs & 20 & 12 & 6 & 90 & 1.02 \\
\hline & adults & 16 & & & & 0.98 \\
\hline \multirow{3}{*}{$\begin{array}{l}\text { second and third } \\
\text { instars }\end{array}$} & larvae & 20 & 0 & 0 & $0(*)$ & \\
\hline & nymphs & 20 & 0 & 0 & $0\left({ }^{*}\right)$ & \\
\hline & adults & 15 & & & & 0.76 \\
\hline $\begin{array}{l}\text { fourth instars } \\
\text { (and pupae) }\end{array}$ & adults & 12 & & & & 0.50 \\
\hline
\end{tabular}

(*) Did not develop beyond nymphal stages. 
not develop on this prey to adulthood, except when fed on eggs and larvae. When larvae of $A$. swirskii bred on 2 nd and 3 rd instars they died in the nymphal stage. The $A$. swirskii used in those experiments was a strain which had been bred in the laboratory for 9 years and was well adapted to pollen of $C$. edulis. This strain is characterized by low fecundity, and thus, additional experiments should be carried out with field-collected mites.

\section{DISCUSSION, CONCLUSION}

Mites of the family Phytoseiidae are known as predators of whiteflies. A. swirskii and E. rubini are effective predators of the tobacco whitefly, Bemisia tabaci (Gennadius) (TEICH, 1966; SWIRSKI et al., 1967). The immature stages of $B$. tabaci were also attacked by 3 additional phytoseiids: Typhlodromus medianicus Elbadry, T. sudanicus Elbadry (ELBADRY, 1967) and Amblyseius aleyrodis
Elbadry 1967 (ElbadRY, 1967 ; GameEL, 1971). The last mentioned develops and reproduces, as well as or better, on pollen or mites than on $B$. tabaci (ELBADRY, 1968). A. aleyrodis attacks the immature stages of $B$. tabaci and reaches a very high oviposition rate : 1.8 progeny on whitefly nymphs and 1.07 on whitefly eggs, per female per day (ELBADRY, 1968); E. rubini, fed on the same food, had an average of 0.68 progeny (TEICH, 1966 ; SWIRSKI et al., 1967). In addition to E. rubini and $A$. swirskii, 4 other species are found in avocado orchards of Israel : Typhlodromus athiasae Porath \& Swirski (SwIRSKI et al., 1981, 1982), Seiulus amaliae Ragusa \& Swirski (SwIRSKI, 1980), Amblyseius largoensis Muma and Iphiseius degenerans Berlese, which was observed in one case to prey on $P$. myricae (SWIRSKI et al., 1982). The predation of $P$. myricae by phytoseiid mites is one example of the adaptation of local natural enemies to a newly introduced pest.

Reçu le 4 janvier 1983. Accepté le 13 avril 1983.

\section{REFERENCES}

Anon., 1978. Cooperative Plant Pest Report 3 (43-44): 617.

Elbadry E. A., 1967. Three new species of phytoseiid mites preying on the cotton whitefly Bemisia tabaci in the Sudan (Acarina: Phytoseiidae). Entomologist, 100, 106-111.

Elbadry E. A., 1968. Biological studies on Amblyseius aleyrodis, a predator of the cotton whitefly. Entomophaga, 13, 323-329.

Gameel O. I., 1971. The whitefly eggs and first larval stages as a prey for certain phytoseiid mites. Rev. Zool. Bot. agric., 84, 79-82. Ishii T., 1938. Description of six new species belonging to Aphelinae from Japan. Kontyu, 12 (1), 27-32.

Kuwana I., 1927. On the genus Bemisia found in Japan with description of a new species. Annot. Zool. Jap., 11, 245-253.

Ragusa S., Swirski E., 1977. Feeding habits, post-embryonic and adult survival, mating, virility and fecundity of the predacious mite Amblyseius swirskii (Acarina, Phytoseiidae) on some coccids and mealybugs. Entomophaga, 22, 383-392.

Rose M., DeBach P., Wooley J., 1981. Potential new citrus pest : Japanese bayberry whitefly. Calif. Agric., 35, 22-24.

Sternlicht M., 1979. A new species of whitefly in Israel. Hassadeh, 59, 1830-1831. (in Hebrew).

Swirski E., 1980. Biology and ecology of phytoseiid mites on subtropical fruit trees of Israel. XVI Int. Congr. Entomol. (Kyoto), Abstr. No. 185-13, p. 451.

Swirski E., Amitai S., Dorzia N., 1967. Laboratory studies on the feeding, development and reproduction of the predaceous mites Amblyseius rubini Swirski \& Amitai and Amblyseius swirskii Athias (Acarina, Phytoseiidae) on various kinds of food substances. Israel J. agric. Res., 17, 101-119.
Swirski E., Izhar Y., Wysoki M., Blumberg D., 1980a. Preliminary information on the phenology and biology of the whitefly Parabemisia myricae on citrus and avocado. Alon haNotea, 34, 627-635. (in Hebrew).

Swirski E., Izhar Y., Wysoki M., Blumberg D., 1980b. Overwintering of the whitefly Parabemisia myricae. Alon haNotea, 35, 71-75. (in Hebrew).

Swirski E., Wysoki M., Izhar Y., 1981. Survey of avocado pests and their natural enemies (1978-1980). Div. of Entomology, Agricultural Research Organization, Bet Dagan, Israel. 38 p. (mimeo, in Hebrew).

Swirski E., Wysoki M., Izhar Y., 1982. Survey of avocado pests and their natural enemies (1981-1982). Div. of Entomology, Agricultural Research Organization, Bet Dagan, Israel. 14 p. (mimeo., in Hebrew).

Teich Y., 1966. Mites of the family Phytoseiidae as predators of the tobacco whitefly, Bemisia tabaci Gennadius. Israel J. agric. Res., 16, $141-142$

Wysoki M., Swirski E., 1971. Studies on overwintering of predacious mites of the genera Amblyseius Berlese, Typhlodromus Scheuten and Iphiseius Berlese (Acarina, Phytoseiidae) in Israel. Entomol. Essays to Commemorate the Retirement of Prof. $K$. Yasumatsu, Tokyo, pp. 265-292.

Yasumatsu K., Watanabe Ch., 1965. A tentative catalogue of Insect Natural Enemies of Injurious Insects in Japan. Part 2. Host Parasite Predator Catalogue. Kyushu Univ. Faculty of Agriculture, Fukuoka, Japan. 